\title{
A Multifunction Infant Incubator Monitoring System with Phototherapy and ESP-32 Based Mechanical Swing
}

\author{
Rafa Raihan Fadilla ${ }^{*}$, Andi Nurul Isri Indriany Idhil ${ }^{2}$, Monika Ayu Puji Anggraini ${ }^{3}$, \\ Ajeng Kusuma Dewi ${ }^{4}$, Mochammad Rofi Sanjaya ${ }^{5}$, Muhammad Yogi Nurrohman ${ }^{6}$, \\ Rahmadwati $^{7}$ \\ 1,4,5,6 Department of Electrical Engineering, Faculty of Engineering, Brawijaya University, \\ Malang, East Java 65145, Indonesia. \\ 2,3 Department of Medical Education, Faculty of Medicine, Brawijaya University, Malang, East \\ Java 65145 , Indonesia. \\ ${ }^{*}$ Corresponding author: \\ Email: rafarfadilla@gmail.com
}

\begin{abstract}
.
Many infant mortality rates are due to premature events. Premature babies are at high risk for hypothermia and hyperbilirubinemia. To overcome this, an incubator can be used as a warmer and light therapy as blue light therapy for yellow babies. However, both medical devices have still been found using manual control. If the health worker is tired of working and manually controlling both devices, it can put the baby at risk. Multifunctional infant incubator based on ESP32, which is an infant incubator equipped with phototherapy and a mechanical swing. This multifunctional baby incubator has the ability to warm the baby's body, the baby yellow light therapy, and can calm the baby when crying. This tool can be monitored remotely using the Internet of Things (IoT). The sensors used are the DHT22 sensor and the sound sensor. Multifunctional baby incubator can make it easier for hospital or basic health care facility level to monitor baby's health in real time without being at the device location and the resulting data can be stored neatly.
\end{abstract}

Keywords: Internet of things, monitoring, incubator, phototherapy.

\section{INTRODUCTION}

Gestation age is a factor influencing infants' survival and life quality. Preterm infants possess a higher mortality risk than the term ones. It is because of their difficulties in adapting to life outside the womb due to their body organs immaturity [21]. WHO defines preterm as labor before gestation age of 37 weeks or less than 259 days calculated from the last menstruation's first day. Preterm birth is classified into three groups based on the gestation age, namely:

- Extremely preterm $(<28$ weeks)

- Very preterm $(28-<32$ weeks $)$

- Moderate or late preterm (32 - <37 weeks of gestation age)

The number of preterm births is estimated for 15 million babies to encounter long-term complications. Almost one million children died annually due to preterm 
birth complications, where more than $60 \%$ of preterm births occur in Africa and South Asia. Meanwhile, low- and moderate-income countries have higher disease loads with preterm births. WHO also noted that Indonesia is the 9th of the top 11 countries with preterm birth rates of more than $15 \%$, and 5 th of the top 10 preterm birth contributors worldwide with a preterm birth number of 15.5 per 100 live births [26].

Infant health problems are even more complicated in low birth weight ones. Preterm infants need special care, even intensive. One of the problems in preterm infants is hypothermia [15]. Preterm infants rapidly experience body heat and become hypothermia because of their non-well-functioned central heat regulation, low metabolism, and relatively wide body surface. Therefore, preterm births have to be treated in incubators so that their body heat will be equal to or come close to heat in the uterus [16].

In 1997, WHO classified hypothermia to four categories based on definitions of normothermia and hypothermia:

- $\quad \operatorname{Normal}\left(36.5-37.5^{\circ} \mathrm{C}\right)$

- Mild hypothermia $\left(36.0-36.5^{\circ} \mathrm{C}\right)$

- Moderate hypothermia $\left(32.0-36.0^{\circ} \mathrm{C}\right)$

- Severe hypothermia $\left(<32.0^{\circ} \mathrm{C}\right)$

Besides hypothermia, preterm infants are also at risk of jaundice or hyperbilirubinemia as infections and coupled with mortality and disability risks [10]. Approximately $50 \%-70 \%$ of term infant births and $80 \%-90 \%$ preterm infant births experienced hyperbilirubinemia [5]. Hyperbilirubinemia is a physiological condition on infants with clinical symptoms such as skin color change and yellowing sclera due to high bilirubin [8].

An incubator is needed to tackle hypothermia. An infant incubator is a medical equipment to maintain temperature stability in a room to remain stable in the predetermined temperature [1]. An infant incubator is generally used for preterm infants who cannot adapt to the surrounding environment. An infant incubator decreases the temperature gradually to comfort babies [12]. The infant incubator's temperature is maintained at the normal range of $33^{\circ} \mathrm{C}$ to $35^{\circ} \mathrm{C}$. Besides, relative humidity of $40 \%$ to $60 \%$ is necessary to be maintained to help stabilize the infant's body temperature [22].

Phototherapy action is a method to decrease the blood bilirubin level [4]. Initially, it was carried out naturally using the sunlight. However, the limited effective lighting time, in which can only be carried out from $07.00-09.00$ in the morning, makes this therapy cannot be carried out throughout the day [9]. In tackling this problem, therapy equipment from artificial light, commonly called blue light therapy, is utilized. This therapy equipment uses a lamp radiating a blue light spectrum with a wavelength of 400-520 $\mathrm{nm}$. Phototherapy typically uses blue, green, or blue-green lamps. However, the blue light may affect infants' skin. In minimizing such effects, the blue light is combined with white light [20]. The radiating distance between infants 
and the light source during the therapy is $+30-50 \mathrm{~cm}$ [9]. Besides being affected by light beam wavelength, phototherapy effectiveness also depends on the light intensity (irradiance), the distance between the lamp and infants, and the infants' body surface area exposed to the light beam [3]. The higher the light intensity and the closer the phototherapy distance, the faster the bilirubin level reduction [20]. Based on the broader illumination area and higher intensity, fluorescent lamps' blue light is more effective than the blue light of LED lamps [17].

Development and studies regarding incubators have extensively conducted [11] developed an infant incubator with automatic on-off control that was economical for delivery clinics.

Various control method was implemented in the development of [14] incubator, i.e., "The Development of Infant Incubator and Wireless-Based Monitoring System" that could control and monitor the infant incubator's temperature wirelessly. However, the equipment was still using several separate components, such as Atmega8535 microcontroller, modern radio of YS-1020B frequency, LM35DZ sensor, and SHT11 humidity sensor. [24] developed an incubator with PID control to regulate the temperature using heater and fan. [28] reviewed the implementation of indirect adaptive generalized predictive control (IAGPC) on a neonatal incubator, which was more effective in controlling temperature than using the on-off and PID. [6] utilized ANFIS control to control the temperature inside of the incubator. [27] developed an incubator to monitor the temperature and humidity from afar using two sensors, i.e., the DS18B20 sensor and the DHT11 sensor. [2] developed an incubator with Raspberry Pi as a single board computer utilized in a monitoring system and using DHT11 as the sensor. [23] developed an incubator based on the Arduino Uno ATmega328 to monitor the temperature and humidity.

Several incubator development studies augmented incubator functions. [7] developed an automatic incubator equipped with phototherapy, biometric fingerprint reader, long-distance monitoring, and heart rate control module for developing countries. [19] developed a portable and wireless incubator using wifi and infrared to measure heart rate, the oxygen level in the blood, and temperature. [18] developed an incubator equipped with phototherapy, long-distance monitoring, and warning equipment that buzzed when the baby cries.

With these advances, the author also developed an incubator equipped with phototherapy and ESP32-based long-distance monitoring. Besides, it was equipped with a mechanical swing to calm babies when they cried. The sensor used was the DHT22 that could read the temperature and humidity and sound sensor to detect babies' cries. Both sensors were integrated, which made the system efficient. 


\section{METHODS}

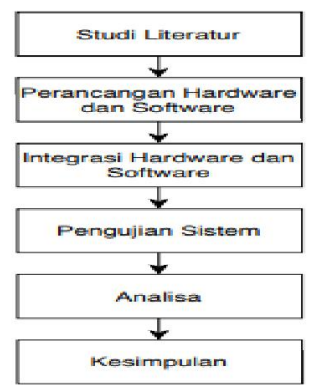

Fig. 1. Study Framework

It is visible from figure 1 that the study process was initiated with a literature study. In this step, the author learned and read literature regarding the study. Literature used as references were scientific journals, books, or sources from the Internet. Then, the author designed the hardware, software, and electronic series scheme.

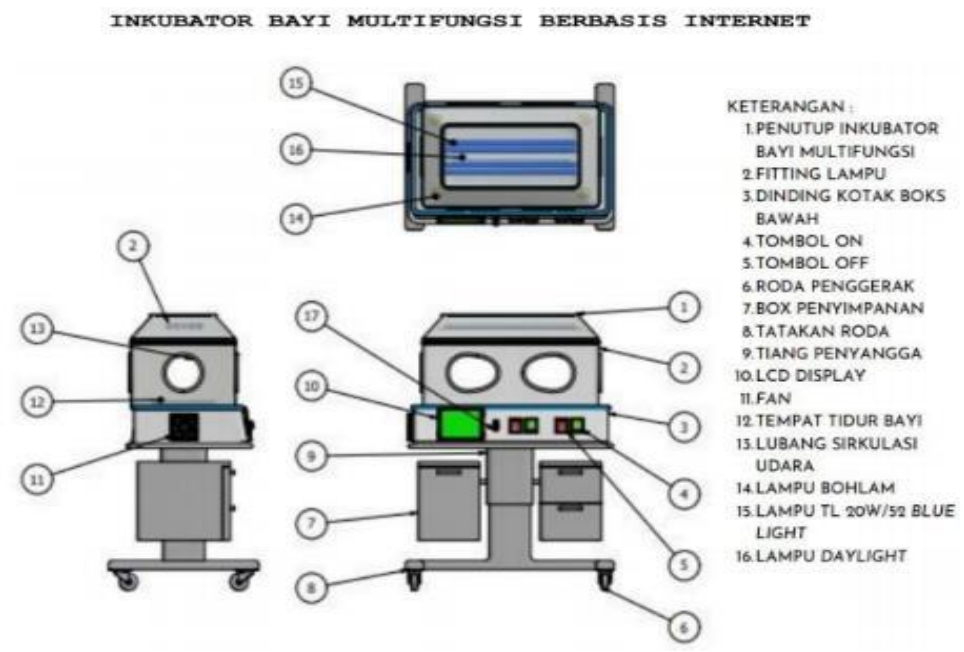

Fig. 2. Designing Image

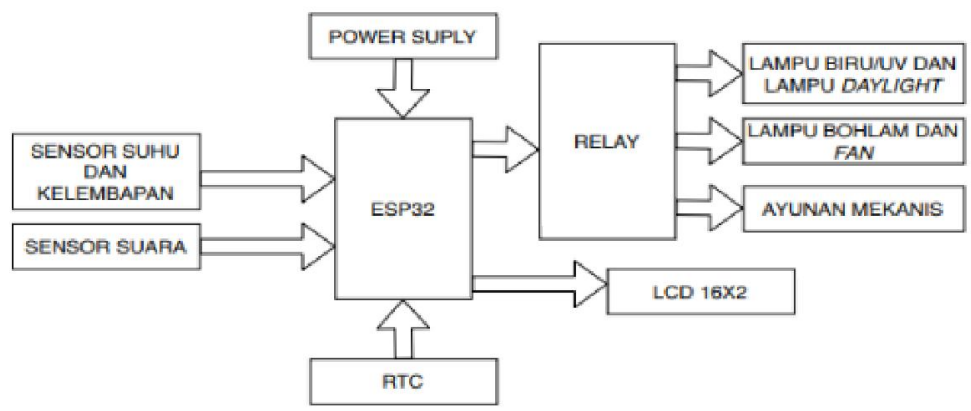

Fig. 3. Hardware Block Diagram

http://ijstm.inarah.co.id 
On the hardware designing step, the author created a design according to figure 2. The material used on the infant incubator wall was acrylic of $60 \times 40 \times 40 \mathrm{~cm}^{3}$. The bottom crib box consisted of electronic components that function to run the system on the equipment. The bottom crib box's size was $70 \times 50 \times 15 \mathrm{~cm}^{3}$. Acrylic was put in the primary frame, and holo iron was utilized so that the multifunction infant incubator wall was installed firmly. The mechanical swing was set under the multifunction infant incubator so that the movement did not crash into the multifunction infant incubator wall.

The sound and DHT22 sensors were installed on the base of the multifunction infant incubator. Inside the bottom box, there were the buzzer, relay, RTC, ESP32, motor stepper, fan, driver motor, and light bulb. On the cover of the multifunction infant incubator, a phototherapy lamp and indicator lamp fitting were installed. Four TL $20 \mathrm{~W} / 52$ blue light lamps and one daylight lamp were installed. The daylight lamp was installed to neutralize the light of TL $20 \mathrm{~W} / 52$ blue light that might affect infants' skin. Meanwhile, the ON button, OFF button, LCD, and push-button were installed on the bottom crib box wall.

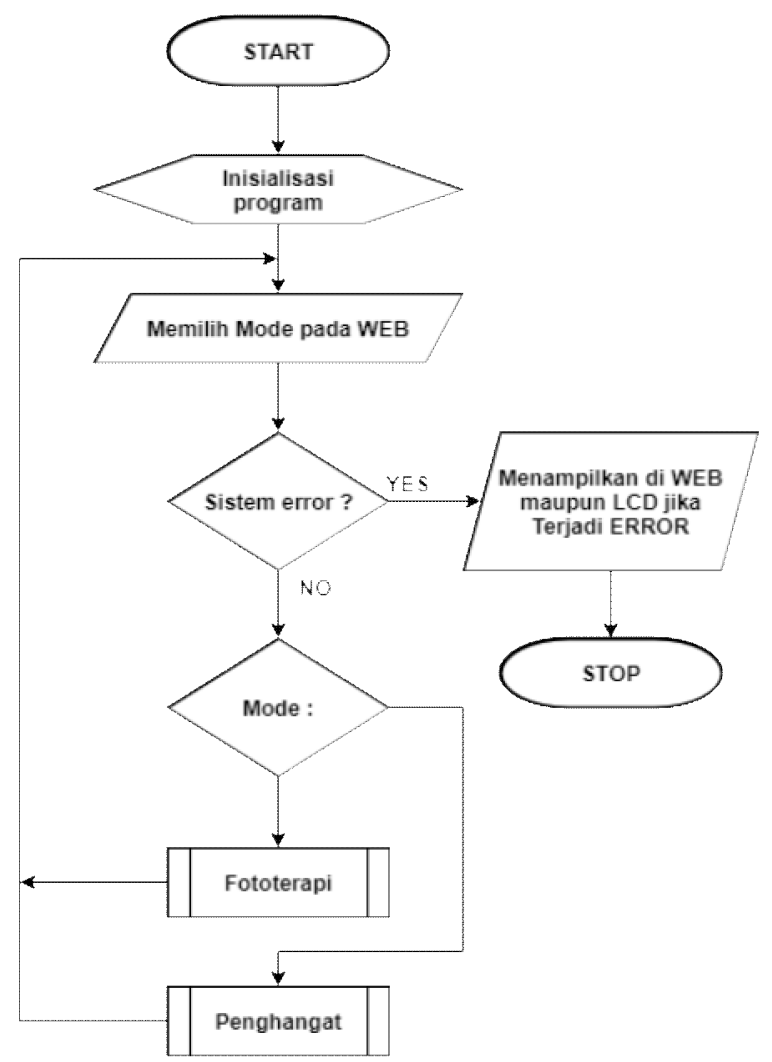

http://ijstm.inarah.co.id 
International Journal Of Science, Technology \& Management
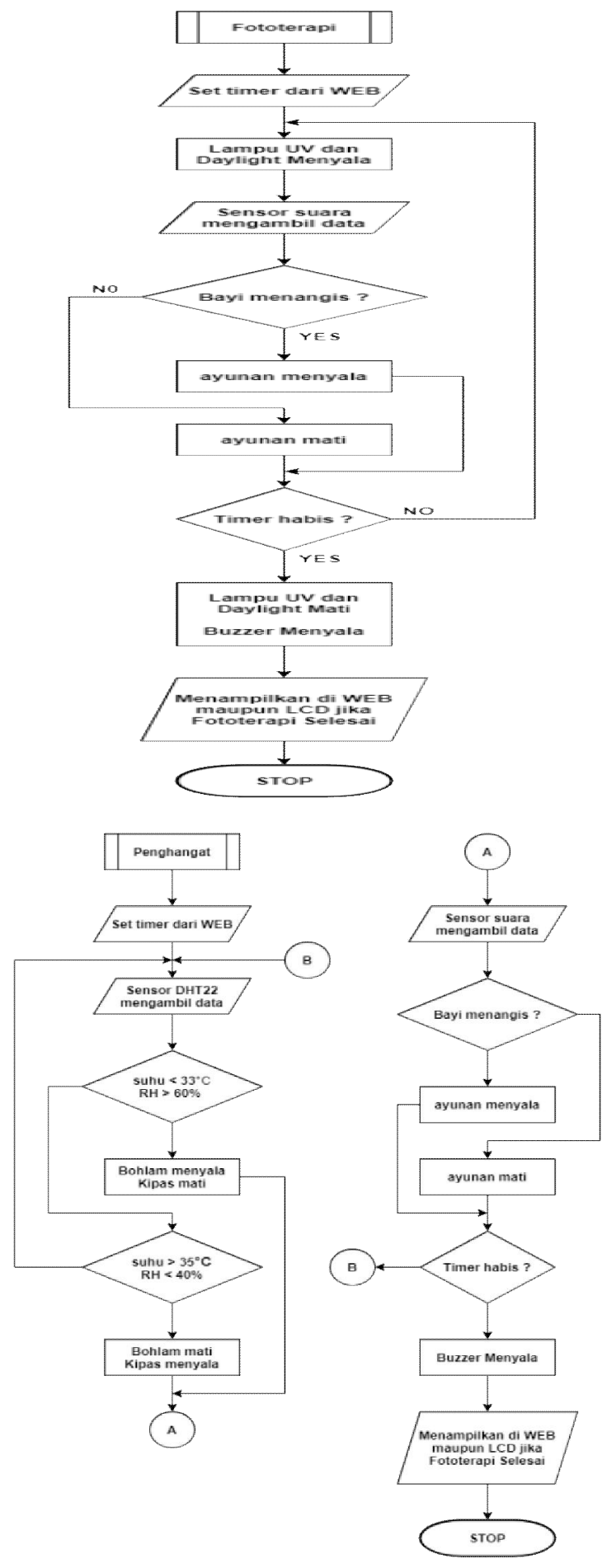

Fig. 4. Flow Diagram

http://ijstm.inarah.co.id 
Then, on the software designing step, the author built the software, which is the overall study's system flow.

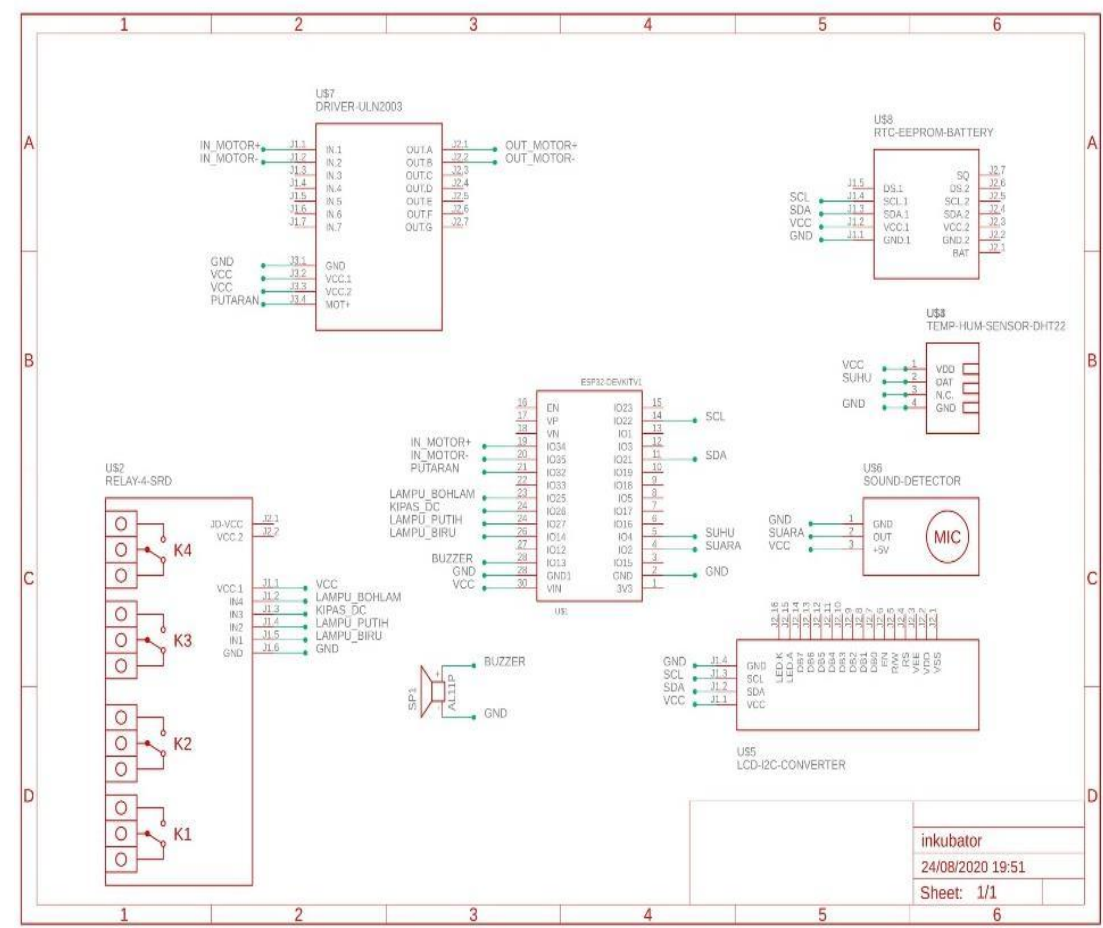

Fig. 5. Overall Electronic Series

In the overall electronic series, all electronic series were present. They were the LCD series, EDP32 series, DHT22 temperature sensor series, sound sensor series, RTC series, and relay series, as illustrated in figure 4 . Figure 4 presents the overall electronic series used in this equipment system.

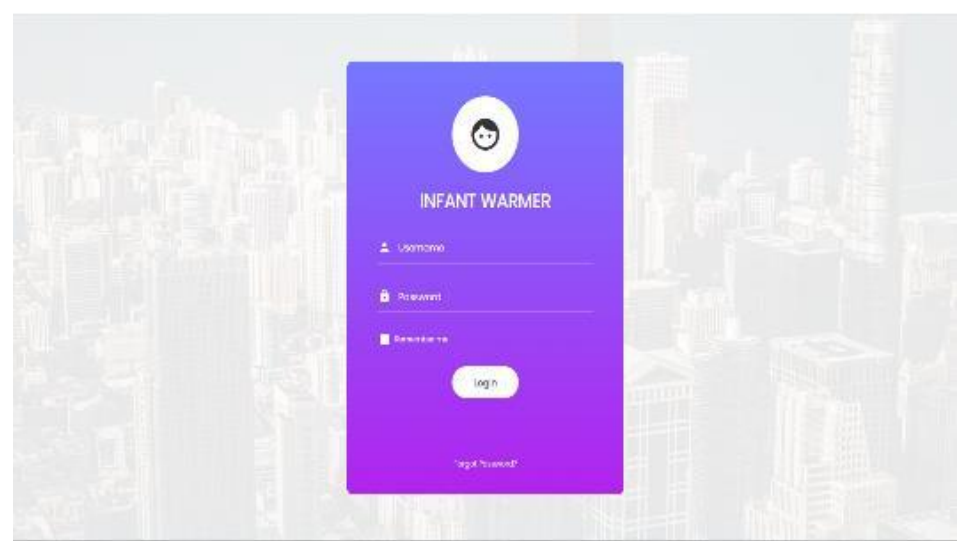

Fig. 6. Web Monitoring Display

The equipment application could be accessed in PC browsers or mobile phones. One should type https://imorat-ink.id on the browser URL. The account creation was adjusted to the channel creation to monitoring the equipment. The http://ijstm.inarah.co.id 
web monitoring display is presented in figure 5. On the hardware and software integration step, the author connected both wares to be a system that worked thoroughly and continuously. Then, a separate and thorough equipment testing was carried out in a system. On the analysis and conclusion step, the author concluded the study results to provide the desired result.

\section{RESULT AND DISCUSSION}

Several testing and analyses were carried out on all inputs and outputs on the results and discussion section. Sensor testing and analysis were necessary to discover whether the sensor was working properly as input according to the plan. Sensor calibration was conducted to ensure the sensor was working in order.

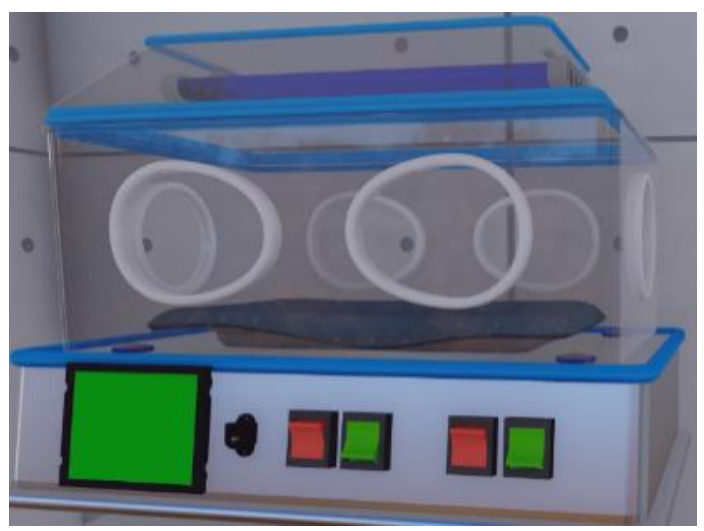

Fig. 7. Overall Equipment Shape

Testing the temperature and humidity control in the incubator system

The temperature set point and normal humidity were $33-35^{\circ} \mathrm{C}$ and $40 \%-60 \% \mathrm{RH}$ on the incubator's temperature control. Temperature, humidity, lamp condition, and fan condition analyses were carried out based on the testing results. When the temperature $>35^{\circ} \mathrm{C}$ and $\mathrm{RH}<40 \%$, four light bulbs were off, and the fan was on to minimize temperature increase. If the temperature $<33^{\circ} \mathrm{C}$ and $\mathrm{RH}>60 \%$, light bulbs were on, and the fan was off to maintain the infants' temperature and humidity stability. These conditions occurred periodically. When the baby cried, the buzzer would sing twice, and the mechanical swing was automatically moving, and the baby is expected to calm down. If the timer was running out, four light bulbs were off, and the buzzer was ringing thrice. 


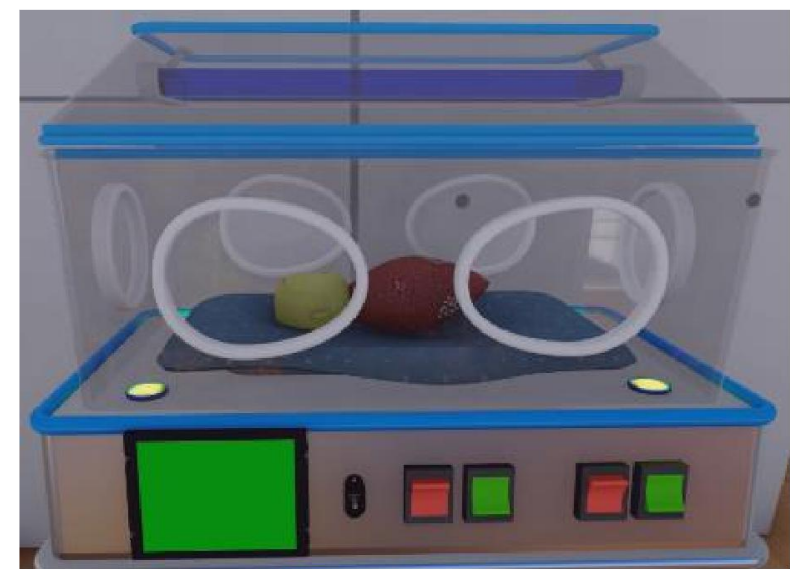

Fig. 8. Temperature, Humidity, and Mechanical Control on the Incubator System

- $\quad$ Testing the phototherapy system

Users input the previous bilirubin level value. The LCD would then display the bilirubin level value and humidity, coupled with a running timer. When the humidity $<$ $40 \% \mathrm{RH}$, the fan would turn on. If the humidity $>60 \% \mathrm{RH}$, the fan would turn off. When the baby cried, the buzzer ringed twice, and the mechanical swing would automatically move, and the baby is expected to calm down. If the timer was running out, four TL $20 \mathrm{~W} / 52$ blue light lamps and one daylight lamp were off, marked by the buzzer that ringed thrice.

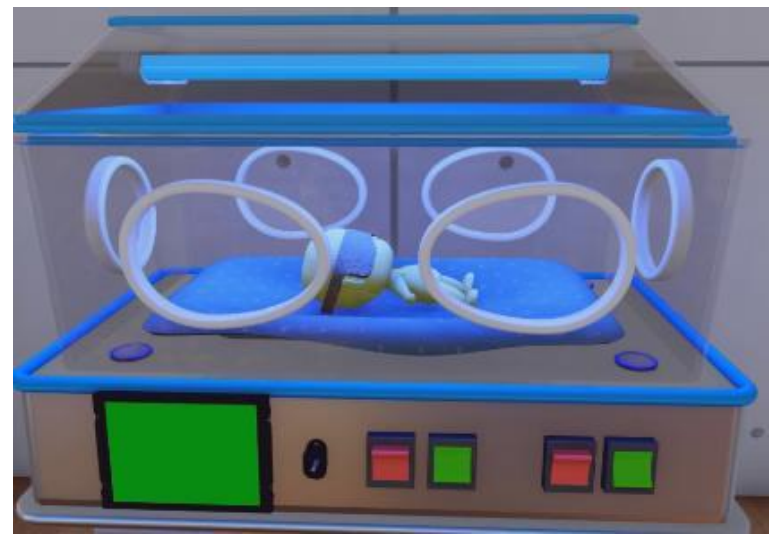

Fig. 9. Humidity and Mechanical Swing Control on the Phototherapy System

\section{CONCLUSION}

Based on the study conducted and discussion explained, it is concluded that the ESP32-based multifunction infant incubator is appropriate to be utilized in hospital institutions and primary healthcare services using manual monitoring. Besides the long-distance monitoring, the infant incubator was equipped with phototherapy and a mechanical swing to calm babies when they cried. On the temperature $>35^{\circ} \mathrm{C}$ and $\mathrm{RH}$ http://ijstm.inarah.co.id 
International Journal Of Science, Technology \& Management

$<40 \%$, four light bulbs were off, and the fan was on to minimize temperature increase. Meanwhile, on the temperature $<33^{\circ} \mathrm{C}$ and $\mathrm{RH}>60 \%$, light bulbs were on, and the fan was off to maintain the infants' temperature and humidity stability. These conditions occurred periodically.

\section{ACKNOWLEDGMENTS}

The authors are grateful to Ristekdikti and Brawijaya University for supporting this research program.

\section{REFERENCES}

[1] Apriyadi, M. R. 2018. Miniatur Pemantau Suhu Inkubator Bayi Berbasis Mikrokontroler Atmega 8535 dan Jaringan Nirkabel. Fakultas Ilmu Komputer dan Teknologi Informasi Universitas Gunadarma, Depok.

[2] Barri, R., Atthariq \& Nasir, M. 2017. Penerapan Sistem Monitoring dan Pengaturan Suhu dan Kelembaban pada Inkubator Bayi Menggunakan Single Board Computer. Jurnal Teknologi Rekayasa Informasi dan Komputer. 1(1): 30-33.

[3] Brandao, D. C. B. et al. 2014. LED versus Daylight Phototherapy at Low Irradiance in Newborns $>=35$ Weeks of Gestation: Randomized Controlled Trial. The Journal of Material-Fetal \& Neonatal Medicine. 28(14): 1-21.

[4] Gomella, T. L. 2009. Hyperbilirubinemia Indirect (Unconjugated Hyperbilirubinemia) : Management, Procedures, On-Call Problems, Disease, and Drug. Edisi ke-7. Lange Medical Books.

[5] IDAI. 2011. Pedoman Pelayanan Medis Ikatan Dokter Anak Indonesia. Edisi ke-1, Badan Penerbit Ikatan Dokter Anak Indonesia. Jakarta.

[6] I, I. E., E, O. O., P, C. E. \& P, U. O. 2019. Improving The Control of Preterm Infant Mass Skin Temperature Using Adaptive Neuro Fuzzy Inference System. International Journal of Research in Engineering \& Science. 3(3): 1-10.

[7] Kapen, P. T. et al, 2019. Development of A Neonatal Incubator with Phototherapy, Biometric Fingerprint Reader, Remote Monitoring, and Heart Rate Control Adapted for Developing Countries Hospitals. Journal of Neonatal Nursing. 25(6): 298-303.

[8] Maisels, M. J. et al. 2009. Hyperbilirubinemia in the Newborn Infant $>=35$ Weeks' Gestation: An Update With Clarifications. Pediatrics. 124(4): 1193-1198.

[9] Maulida, L. T. 2013. Ikterus Neonatorum. PROFESI. 10(1): 39-43.

[10] Mwaniki, M. K., Atieno, M., Lawn, J. E. \& Newton, C. R. J. C. 2012. Long-term neurodevelopmental outcomes after intrauterine and neonatal insults: A Systematic Review. 379(9814): 445-452.

[11] Nurlandi, F. 2010. Desain Inkubator Bayi dengan Kontrol Otomatis yang Ekonomis untuk Klinik Persalinan (ECUBATOR). Skripsi. Fakultas Teknik Sipil dan Perencanaan Institut Teknologi Surabaya, Surabaya.

[12] Pratiwi, D. P., Rizal, A. \& Hadiyoso, S. 2014. Pemantau dan Pengatur Suhu Inkubator Bayi Berbasis WIFI. Skripsi. Fakultas Teknik Elektro Universitas Telkom, Bandung. 
International Journal Of Science, Technology \& Management

[13] Proverawati, A. \& Sulistyorini. 2010. BBLR (Berat Badan Lahir Rendah). Yogyakarta: Nuha Medika.

[14] Ramdhani, W. 2013. Pengembangan Inkubator Bayi dan Sistem Monitoring Berbasis Wireless. Tesis. Fakultas Teknik dan Ilmu Komputer Universitas Komputer Indonesia, Bandung.

[15] Rustina, Y. 2015. Bayi Prematur: Perspektif Keperawatan. Jakarta: CV Agung Seto.

[16] Proverawati, A. \& Sulistyorini. 2010. BBLR (Berat Badan Lahir Rendah). Yogyakarta: Nuha Medika.

[17] Santiari, D. A. S. \& Putra, P. A. M. 2018. Kajian Area Penyinaran dan Nilai Intensitas pada Peralatan Blue Light Therapy. Majalah Ilmiah Teknologi Elektro. 17(2): 279-286.

[18] Setyaningsih, E., Tommy \& Tanudjaja, H. 2019. Sistem Pemantauan Inkubator Bayi Menggunakan Jaringan Wifi dan Berbasis Database. TESLA. 21(2): 59-69.

[19] Shaib, M. et al. 2017. Advanced Portable Preterm Baby Incubator. Fourth International Conference on Advances in Biomedical Engineering (ICABME). 19-21 Oktober 2017, Beirut, Lebanon. pp 1-4.

[20] Stokowski, L. A. 2011. Fundamentals of Phototherapy for Neonatal Jaundice. Advances in Neonatal Care. 11(5S): S10-S21.

[21] Sulistiarini, D. \& Berliana, S. M. 2016. Faktor-Faktor yang Memengaruhi Kelahiran Prematur di Indonesia: Analisis Data Riskesdas 2013. E-Journal Widya Kesehatan Dan Lingkungan. 1 (2): 109-115.

[22] Surasmi, A., Handayani, S. \& Kusuma, H. N., 2003. Perawatan Bayi Risiko Tinggi. Buku Kedokteran EGC. Jakarta.

[23] Taqwa, A., Sholihin \& Romansyah, E. 2020. Monitoring Temperture Bayi dengan Sistem Wireless Sensor Network Berbasis Arduino Uno Atmega328. CYCLOTRON. 3(2): 53-57.

[24] Theopaga, A. K., Rizal, A. \& Susanto, E., 2014. Design and Implementation of PID Control Based Baby Incubator. Journal of Theoritical and Applied Information Technology. 7(1): 19-24.

[25] WHO, 1997. Thermal Control of the Newborn: a Practical Guide. Geneva: Maternal and Safe Motherhood Programme, Division of Family Health.

[26] WHO, 2012. Born Too Soon: the global action report on preterm birth. s.1.:March of Dimes, PMNCH, Save the Children, WHO.

[27] Wijaya, R. A., Lestari, S. W. \& Mardiono. 2018. Rancang Bangun Alat Monitoring Suhu dan Kelembaban pada Alat Baby Incubator Berbasis Internet of Things. Jurnal Teknologi. 6(1): 52-70.

[28] Zermani, M. A., Feki, E. \& Mami, A. 2011. Application of Adaptive Predictive Control to a Newborn Incubator. American Journal of Engineering and Applied Sciences. 4(2): 235243. 